\title{
John Stott (1921-2011) En evangelikal kyrkofader
}

\author{
Per-Axel Sverker \\ per-axel.sverker@telia.com
}

Som protestanter är vi tveksamma till att helgonförklara människor. Ändå är det av betydelse att hitta goda föredömen för både tanken och livet. För många kristna är John Stott (1921-2011) en sådan gestalt. Han har blivit kallad "en av nittonhundratalets kyrkofäder". Under 2021 skulle Stott alltså ha fyllt hundra år.

John Stott var en mycket inflytelserik ledare och teolog bland evangelikaler i England men också internationellt. Detta inflytande grundar sig på ett framgångsrikt församlingsarbete, ett omfattande författarskap och en framträdande roll vid konferenser och inom kommittéer. John Stott gjorde sig känd för sin pedagogiska skicklighet och teologiska gedigenhet, som blev uppenbara i flera böcker, varav många nu är klassiker. Under flera år producerade han också bibelkommentarer, som är mycket användbara genom sin föredömliga balans mellan bibeltolkning och förkunnelse.

\section{John Stott som förkunnare}

Stotts författarskap utgår från en klassisk evangelikal teologi. Men han stannar inte $i$ en försvarsposition för en traditionell lära. Stott går i närkamp med tidens utmaningar. Det kan gälla inomkyrkliga frågor men också problem av allmänmänskligt slag. Stott önskade förmedla en undervisning, som svarade på de nya utmaningar, som mötte de kristna. Han var övertygad om att en medveten reflektion behövs.

Den pedagogiska reflektionen som karaktär på Stotts böcker förklaras av att han under många år var kyrkoherde i All Souls Church i centrala London. Församlingen ägnade sig åt progressiv evangelisation men blev mest känd för Stotts förkunnelse. Under 25 år var han synnerligen engagerad i studentarbete i England men också i andra länder. Från 1970 ägnades alltmer tid åt ledarseminarier och studentkonferenser i majoritetsvärlden. Det har visat sig att hans insatser bland majoritetsvärldens kristna bidrog till att vitalisera de viktigaste delarna av den evangelikala rörelsen genom hans fokusering på Bibelns och korsets centrala ställning inom kristet liv.

\section{John Stott som ledare}

Många kristna ledare i majoritetsvärlden betraktade "Uncle John" som ett slags "ärkebiskop" i hans rådgivande funktion. Stott besökte över hundra länder och valde denna globala tjänst framför att bli biskop eller collegerektor inom den anglikanska kyrkan. Under trettio år av utlandsresor omfattade Stotts mentorskap hundratals personer, varav flera nu är ledare för kyrkor med miljoner medlemmar. Stott bidrog på ett betydelsefullt sätt 
till den explosiva tillväxten i dessa länder.

Inom det interna arbetet för den evangelikala rörelsen i England har Stott haft en avgörande betydelse. Stott ägnade sig åt att stärka den evangelikala saken inom den anglikanska kyrkan men också åt att vidga dialogen med andra grupper. Mest känd är han dock för insatserna på det internationella planet. Han var medlem av exekutivkommittén vid Lausanne-konferensen 1974 och författare till Lausannedeklarationen. Som huvudsaklig författare till denna deklaration har han gett ett bestående bidrag till församlingens globala mission.

Hans erfarenheter från England hade lärt honom dialogens betydelse för att lyssna till vad andra säger om sin tro. I sitt arbete i majoritetsvärlden med dess utmaningar till religionsdialog har Stott visat att tolerans inte behöver utgå från ett relativt sanningsbegrepp utan är en fråga om en ödmjuk karaktär. Det är den troende som person som är tolerant, inte hans åsikter som är toleranta. Om teologins sanning blir relativ, kommer likgiltighet att ersätta övertygelsen. Stotts teologi visar på glädjen i en djup sanningsövertygelse.

\section{Bibeltolkning som historiskt studium och i vördnad}

Som förkunnare gav Stott alltså stor betydelse åt sanningen i de bibliska lärorna. Sanningsfrågan har stått i fokus också för Stotts exegetiska arbete. Den historiskkritiska bibelforskningen har gett positiv utdelning $\mathrm{i}$ form av historiska insikter. Det skulle för Stott vara direkt felaktigt att förneka det. Men det medges idag också av icke-evangelikala teologer att denna historisk-kritiska forskning försvårat för den kristne att närma sig Bibeln i trons förtröstan.

Ett arbete med textens historiska inne- börd är nödvändigt för Stott om dess egenart ska komma fram. Gudsuppenbarelsen har tagit formen av en historisk process. Guds ord om denna uppenbarelse utgörs av en bok om historia. Därför ges kunskap om vad Gud vill uppenbara genom att ta reda på vad de mänskliga författarna verkligen menade.

Till hjälp i detta arbete använder Stott tre tolkningsprinciper, "simplicity, history and harmony", som han anser mycket entydiga, samtidigt som de är grundade i Guds karaktär. Han söker efter den naturliga meningen (simplicity), eftersom Gud önskade att uppenbarelsen ska vara "enkel för dess läsare ... ett klart begripligt budskap", den ursprungliga meningen (history), eftersom den är adresserad till dem som först hörde det och därför bara kan förstås historiskt samt den generella meningen (harmony), som uttrycker Guds tanke, varför Bibeln utgör en organisk enhet, eftersom Gud inte motsäger sig själv.

Skillnaden gentemot den liberala bibelkritiken består i att den närmar sig Bibeln som en vanlig bok, medan evangelikal bibelforskning accepterar dess självvittnesbörd om att utgöra en gudomligt inspirerad bok. Det som för den ena gruppen ses som "fel", blir för den andra gruppen "problem". Stott tolkar exegetikens nya rön som att ett fördjupat studium har klargjort att så kallade "fel" visat sig kunna förklaras.

Men naturligtvis ser Stott ändå problem i Bibeln. Problemen delar Stott in i två kategorier, nämligen de mellan Bibeln och populär naturvetenskap och de mellan olika bibelböcker. Den rimliga attityden bör enligt Stott vara att erkänna dessa problem och försöka lösa dem. För Stott kan ingen kristen troslära omfattas utan intellektuella problem. Inte heller behöver läran om Bibelns inspiration och 
sanning överges på grund av dess problem. Stott säger sig kunna tro på Bibelns sanning trots motsägelser och gåtfulla texter. Försvaret för detta skulle kunna vara att inte heller inom annan forskning behöver en teori överges bara för att den inte kan förklara alla fakta.

I dess egenskap av en mänskligt tillkommen bok är det alltså för Stott legitimt med olika former av litterärt och historiskt studium av Bibeln: "Eftersom det är människors ord ska vi studera den som varje annan bok - använda vårt förstånd, undersöka dess ord och syntax, dess historiska ursprung och dess litterära form". Samtidigt tillägger Stott att eftersom Bibeln är gudomlig uppenbarelse, bör detta studium ske i vördnad: "Men eftersom den också är Guds Ord, ska vi studera den som ingen annan bok, på våra knän, ödmjukt, med rop till Gud om upplysning och om den helige Andes hjälp, förutom vilken vi aldrig kan förstå hans Ord."

En förutsättning enligt Stott för att verkligen höra Guds röst i Skriften är ödmjukhet. Vårt problem med Bibeln är, så som Stott ser det, inte i första hand intellektuellt. Problemet finns istället i hjärtats olydnad: "Men vi kan säkert säga att ingen tolkningsmetod eller slutsats kan vara kristen, som misslyckas med att ära Kristus genom att kröna honom som Herre." Stott vill betona att sann tolkning endast äger rum där det finns en oreserverad avgörelse för kristet lärjungaskap. Detta innebär främst en personlig lojalitet gentemot Jesus Kristus som hela livets Herre, men också i förhållande till Bibeln.

Om vi lydde Bibeln skulle den bli klarare att tolka och vårt budskap skulle bli auktoritativt. Trovärdigheten gäller huruvida kristna lever efter sina tolkningar av Bibeln. Stott efterlyste mer radikala tilllämpningar. Den konservativa inställningen till Bibeln får enbart gälla bevarandet av den unika uppenbarelsen i Kristus och i Bibeln, däremot inte "vad gäller fördomar, eller vår livsstil eller vårt motstånd mot förändring”. Den radikala prövningen ska inkludera även den egna kristna traditionen, för att befrias "från slagord och från stereotyper: "Ingenting är heligt för en radikal konservativ evangelikal utom Skriften själv".

\section{En evangelikal bibeltolkning}

En evangelikal bibelforskning i Stotts gestaltning utgår från sin trosståndpunkt att Bibeln är Guds ord och arbetar i ljuset av detta för att lösa ett specifikt problem. Bibeltolkningen måste utgå från ett trosbeslut om vilken slags bok Bibeln är. På grund av dess dubbla karaktär av gudomligt och mänskligt ord bör den alltså studeras med både historisk undersökning och med vördnad.

Sanningen har inom den evangelikala teologin en historisk dimension som kan prövas på ett objektivt sätt. Men sanningen har också en personlig, existentiell sida. Den har en etisk sida av lydnad mot Guds ord. Biblisk sanning finns enligt John Stott bara där man är inställd på att förstå den och lyda den. 